\title{
Penerapan Pembelajaran Cooperative Integrated Reading and Composition Berbasis Inquiry untuk Meningkatkan Aktivitas dan Hasil Belajar Matematika Siswa Kelas IX-6 SMP
}

\author{
Nuramin \\ Guru SMPN 1 Pujut, nuraminpujut@gmail.com
}

\section{INFO ARTIKEL}

Riwayat Artikel:

Diterima: 01-03-2018

Disetujui: 20-03-2018

Kata Kunci:

CIRC, Inquiry, Aktivitas Belajar,
\end{abstract} dan Hasil Belajar.

\section{A. LATAR BELAKANG}

Matematika merupakan ilmu universal yang mendasari perkembangan teknologi modern, mempunyai peran penting dalam berbagai disiplin ilmu dan memajukan daya pikir manusia. Untuk menguasai dan mencipta teknologi di masa depan diperlukan penguasaan matematika yang kuat. Mata pelajaran matematika perlu diberikan kepada semua peserta didik untuk membekali peserta didik dengan kemampuan berpikir logis, analitis, sistimatis, kritis dan kreatif, serta kemampuan bekerjasama. Kompetensi tersebut diperlukan agar peserta didik dapat memiliki kemampuan memperoleh, mengelola dan memanfaatkan informasi untuk bertahan hidup pada keadaan yang selalu berubah, tidak pasti dan kompetitif.

Oleh karena itu pembelajaran matematika di sekolah terus diupayakan dalam rangka meningkatkan kualitas prestasi belajar siswa.
Berbagai cara terus dilakukan, salah satunya dilakukan dengan mensinergikan komponenkomponen yang terlibat dalam pembelajaran. Komponen yang terlibat dalam pembelajaran tersebut adalah tujuan, bahan pelajaran (materi), kegiatan pembelajaran, metode, alat dan sumber serta evaluasi.

Berdasarkan pengamatan yang dilakukan di sekolah, masih banyak peserta didik yang tidak paham terhadap materi pelajaran yang disampaikan oleh guru, dikarenakan karena pada umumnya guru dalam melaksanakan pembelajarannya di dalam kelas terlalu monoton terhadap semua materi pelajaran matematika sehingga membuat siswa menjadi cepat bosan dan prestasi belajar siswa menjadi menurun. Karena tidak semua materi pelajaran yang diajarkan tidak selamanya menggunakan metode yang sama dalam penyampaiannya. Hal ini terlihat dari ketuntasan 
belajar siswa sebesar 75\%, nilai ini masih jauh dari ketuntasan belajar yang sudah ditetapkan.

Salah satu upaya guru untuk meningkatkan kembali aktivitas dan prestasi belajar matematika siswa adalah dengan melakukan perbaikan metode pembelajaran yang disesuaikan dengan komponen pembelajaran lainnya. Salah satu metode yang dapat guru gunakan adalah pembelajaran cooperative integrated reading and composition (CIRC) berbasis inquiry.

Dalam rangka untuk meningkatkan aktivitas dan hasil belajar siswa maka peneliti mencoba untuk melakukan penelitian dengan judul : Penerapan Pembelajaran Cooprative Integrated Reading and Composition (CIRC) berbasis Inquiry untuk meningkatkan aktivitas dan hasil belajar matematika siswa kelas IX_6 SMP Negeri 1 Pujut semester I tahun pelajaran $2017 / 2018$.

\section{B. METODE PENELITIAN}

Ruang lingkup Penelitian ini adalah siswa kelas IX_6 SMP Negeri 1 Pujut semester I tahun pelajaran 2017/2018 yang terdiri dari 24 siswa dengan komposisi 12 siswa laki-laki dan 12 siswa perempuan pada mata pelajaran Matematika yang dilakukan pada bulan Agustus - Oktober 2017 di SMP Negeri 1 Pujut.

Prosedur yang digunakan dalam penelitian ini adalah prosedur penelitian tindakan kelas. Penelitian tindakan kelas ini direncanakan dalam dua siklus, secara garis besar setiap siklus terdapat empat tahapan yang lazim dilalui, yaitu: (1) perencanaan, (2) pelaksanaan tindakan, (3) pengamatan (observasi), dan (4) refleksi, yang merupakan langkah berurutan dalam satu siklus yang berhubungan dengan siklus berikutnya.

\section{Tahap Perencanaan}

Kegiatan yang dilakukan pada tahap

perencanaan adalah sebagai berikut:

a. Peneliti mensosialisasikan pada siswa kelas IX_6 mengenai pembelajaran kooperatif tipe CIRC Berbasis Inquiry (Penemuan).

b. Peneliti membuat Rencana Pelaksanaan Pembelajaran (RPP).

c. Peneliti menyiapkan LKS atau soal-soal diskusi kelompok.

d. Peneliti menyiapkan lembar observasi aktivitas siswa dan guru. e. Peneliti menyusun tes hasil belajar dalam bentuk pilihan ganda.

\section{Pelaksanaan tindakan}

Kegiatan yang dilakukan pada tahap ini adalah melaksanakan rencana pelaksanaan pembelajaran yang telah direncanakan. Tahap-tahap pelaksanaan tindakan ini adalah: a. Pendahuluan

1) Peneliti mensosialisasikan pada siswa mengenai pembelajaran CIRC Berbasis Inquiry (Penemuan).

2) Peneliti menyampaikan indikator hasil belajar.

3) Peneliti mengorganisasikan kepada siswa agar membentuk kelompok.

4) Guru memberikan motivasi dan apersepsi yang berkaitan dengan materi yang akan dipelajari.

b. Pengembangan

1) Guru membagikan LKS/ Wacana atau materi yang akan didiskusikan kepada masing-masing kelompok, sambil memberi penekanan bahwa mereka akan menyampaikan atau melaporkan hasil diskusinya.

2) Guru memberi kesempatan kepada siswa untuk mengerjakan LKS/Wacana dengan anggota kelompoknya setelah diberikan kesempatan untuk menemukan sendiri.

3) Guru membimbing dan mengarahkan siswa dalam menyelesaikan LKS selama jalannya diskusi.

4) Guru memberi kesempatan tiap-tiap kelompok untuk menyampaikan hasil kerja kelompoknya.

5) Guru memberikan kesempatan kepada siswa untuk memberi tanggapan terhadap hasil diskusi.

\section{c. Penerapan}

1). Guru meminta siswa secara individual untuk mengerjakan soal latihan yang berkaitan dengan hasil diskusinya.

2). Guru menunjuk beberapa siswa untuk menuliskan jawaban dari soal di papan tulis sebagai perwakilan dari kelompoknya.

3). Guru menilai jawaban siswa serta menyampaikan langkah-langkah 
penyelesaian yang benar apabila terdapat kesalahan dari jawaban siswa.

d. Penutup

1) Guru menyampaikan kesimpulan mengenai materi yang telah dipelajari.

2) Guru menginformasikan materi yang akan dipelajari pada pertemuan selanjutnya dan bahan yang harus disiapkan untuk kegiatan berikutnya.

\section{Observasi dan Evaluasi}

Pada tahap ini dilaksanakan observasi terhadap aktivitas siswa saat berlangsungnya peroses belajar mengajar dengan menggunakan lembar obsevasi, apakah sudah sesuai dengan indikator perilaku yang telah di tentukan atau tidak. Pada tahap ini juga dilaksanakan evaluasi terhadap hasil belajar siswa dengan memberikan hasil tes atau ulangan pada akhir siklus serta menganalisa hasil tes tersebut, apakah hasil belajar siswa secara kelasikal sudah tuntas atau belum.

\section{Refleksi}

Hasil yang diperoleh pada tahap observasi dan evaluasi dikumpulkan dan dianalisa pada tahap ini. Dari hasil observasi dan evaluasi pada siklus I guru mengidentifikasi kesalahan dan kekurangan, menganalisis penyebab kekurangan dan merefleksi diri untuk melakukan persiapan menyusun tindakan perbaikan untuk melaksananakan siklus II. Tindakan yang sama juga dilakukan untuk siklus II-III dan selanjutnya.

\section{Analisis Data Data Hasil Belajar}

Data tentang hasil belajar siswa dianalisis secara deskriptif kualitatif. Kualifikasi prestasi belajar siswa diperoleh dengan pedoman konversi seperti Tabel 1 berikut:

TABEL 1

PEDOMAN KONVERSI SKOR HASIL BELAJAR SISWA

\begin{tabular}{ccc}
\hline No & SKOR & KATEGORI \\
\hline 1 & $85-100$ & Sangat Baik \\
\hline 2 & $70-84$ & Baik \\
\hline 3 & $55-69$ & Cukup \\
\hline 4 & $40-54$ & Kurang \\
\hline 5 & $0-39$ & Sangat Kurang \\
\hline
\end{tabular}
(Sujdana N, 1987:120)

Untuk mengetahui adanya peningkatan hasil belajar siswa pada pembelajaran matematika yang dicapai pada tiap siklus, digunakan rumus sebagai berikut:

a. Menentukan Nilai Siswa

$$
N=\frac{\text { Skor Siswa }}{\text { Skor Maksimal }} \times 100
$$

b. Menentukan nilai rata-rata

$$
\bar{X}=\frac{\text { Nilai Siswa }}{\text { Siswa Mengikuti Tes }}
$$

(Sujdana N, 1987:125)

c. Kategori ketuntasan individual

Setiap siswa dalam proses belajar mengajar dikatakan tuntas secara individu terhadap materi pelajaran yang disajikan apabila siswa mampu memperoleh nilai $\geq 60$.

d. Ketuntasan klasikal dinyatakandengan:

$$
K K=\frac{X}{N} \times 100 \%
$$

Kelas dinyatakan tuntas secara klasikal terhadap materi pelajaran yang disajikan jika ketuntasan klasikal mencapai $85 \%$.

\section{Aktivitas Siswa}

Aktivitas siswa dapat diketahui melalui observasi terhadap perilaku siswa selama mengikuti pembelajaran dengan lembar observasi terdiri dari 6 indikator, tiap indikator terdiri dari 3 deskriptor. Data aktivitas siswa dianalisis dengan cara berikut:

a. Menentukan skor untuk tiap deskriptor aktivitas siswa.

b. Menentukan rata-rata skor tiap indikator dilakukan dengan cara menjumlahkan semua skor pada tiap deskriptor dari indikator tersebut kemudian dibagi dengan banyaknya deskriptor pada indikator tersebut.

c. Data aktivitas siswa dianalisis secara deskriptif kualitatif dengan menggunakan skor skala $1-5$, sehingga diperoleh skor maksimal ideal (SMI) adalah skor maksimalnya 3 dikalikan dengan jumlah item aktivitas siswa yang dinilai.

Kualifikasi belajar siswa ditentukan berdasarkan pedoman konversi seperti pada tabel 2 berikut:

TABEL 2

PEDOMAN KONVERSI PENILAIAN SKALA 1-5 AKTIVITAS BELAJAR SISWA.

\begin{tabular}{cc}
\hline SKOR & KUALIFIKASI \\
\hline $\mathrm{MI}+1,5 \mathrm{SDI} \leq \bar{X}$ & Sangat Aktif \\
\hline $\mathrm{MI}+0,5 \mathrm{SDI} \leq \bar{X}<$ & Aktif \\
$\mathrm{MI}+1,5 \mathrm{SDI}$ & \\
\hline $\mathrm{MI}-0,5 \mathrm{SDI} \leq \bar{X}<$ & Cukup Aktif \\
\hline
\end{tabular}




\begin{tabular}{cc}
\hline MI $+0,5$ SDI & \\
\hline MI $-1,5$ SDI $\leq \bar{X}<$ & Kurang Aktif \\
MI - 0,5 SDI & \\
\hline $\bar{X}<$ MI - 1,5 SDI & Sangat Kurang \\
& Aktif \\
\hline \multicolumn{2}{r}{ (Arifin, 2009:237) }
\end{tabular}

\section{Indikator Keberhasilan}

Indikator keberhasilan penelitian ini adalah:

a. Aktivitas belajar siswa minimal berkategori aktif dan mengalami peningkatan skor rata-rata pada tiap siklusnya.

b. Ketuntasan belajar siswa sebesar $85 \%$ dari siswa di kelas yang memperoleh nilai sebesar $\geq 60 \%$ pada saat evaluasi.

\section{HASIL DAN PEMBAHASAN}

\section{Siklus I}

a. Perencanaan

1) Menentukan pengajar dan observer pada pelaksanaan penelitian tindakan kelas ini. Dalam hal ini yang menjadi pengajar adalah peneliti yaitu guru bidang studi dan yang menjadi observer adalah rekan kerja.

2) Menyusun perangkat pembelajaran yang meliputi penyusunan rencana pelaksanaan pembelajaran (RPP), membentuk kelompok yang memiliki kemampuan akademik heterogen dengan anggota $4-5$ orang, pedoman observasi aktivitas guru, pedoman observasi aktivitas siswa, menyiapkan lembar kerja siswa (LKS) sebagai bahan diskusi, dan membuat soal evaluasi lengkap dengan pedoman penskorannya.

b. Pelaksanaan tindakan

Kegiatan yang dilakukan pada tahap ini adalah melaksanakan pembelajaran sesuai dengan Rencana Pelaksanaan Pembelajaran (RPP) siklus I. Adapun langkah yang ditempuh adalah:

1) Guru melaksanakan pembelajaran dengan menjelaskan materi pelajaran. Dengan menggunakan metode $C I R C$, guru mengamati pemahaman konsep yang telah dikuasai siswa. Siswa diberikan kesempatan bertanya terhadap materi yang belum jelas.
2) Guru bersama-sama siswa membentuk kelompok yang beranggotakan 4-5 orang. Ketua kelompok dipilih sesuai kesepakatan dari masing-masing kelompok.

3) Guru membagikan siswa LKS kemudian siswa diminta mengerjakan LKS secara bersama-sama dengan batas waktu yang sudah ditentukan.

4) Setelah berdiskusi dengan teman kelompok, siswa diminta untuk membahas hasil kerjanya dipimpin oleh ketua kelompok.

5) Masing-masing wakil dari anggota kelompok secara bergiliran mengerjakan lembar kerja di papan tulis, siswa yang lain memperhatikan dan memberi tanggapan.

6) Setelah diskusi berakhir, guru memberikan soal latihan yang dijawab bersama dan beberapa pertanyaan untuk mengingatkan materi yang sudah dibahas. Setelah itu guru bersama-sama dengan siswa menyimpulkan apa yang dipelajari pada pertemuan ini.

c. Hasil observasi

1) Observasi aktivitas guru Hasil perhitungan observasi aktivitas guru dapat dilihat pada tabel 3

TABEL 3

HASIL PERHITUNGAN AKTIVITAS GURU SIKLUS I

\begin{tabular}{ccc}
\hline Pertemuan & $\begin{array}{c}\text { Skor aktivitas } \\
\text { guru }\end{array}$ & Katagori \\
\hline 1 & 2,57 & Sangat Baik \\
\hline 2 & 2,71 & Sangat Baik \\
\hline
\end{tabular}

2) Observasi aktivitas siswa

Data mengenai hasil observasi aktivitas siswa untuk siklus I dapat dilihat pada lampiran sekaligus dengan analisisnya. Ringkasan hasil observasi aktivitas siswa dapat dilihat pada Tabel 4 berikut ini:

TABEL 4

RINGKASAN HASIL AKTIVITAS SISWA SIKLUS I

\begin{tabular}{ccc}
\hline Pertemuan & $\begin{array}{c}\text { Skor aktivitas } \\
\text { siswa }\end{array}$ & Katagori \\
\hline 1 & 10,34 & Aktif \\
\hline 2 & 11,34 & Aktif \\
\hline
\end{tabular}

d. Hasil evaluasi 
Evaluasi belajar siswa diadakan pada akhir pertemuan dengan cara memberikan tes berbentuk pilihan ganda sebanyak 10 soal yang dikerjakan dalam waktu dua jam pelajaran. Ringkasan hasil evaluasi siswa dapat dilihat pada tabel 5

TABEL 5

RINGKASAN HASIL EVALUASI SIKLUS

\begin{tabular}{lc}
\hline $\begin{array}{l}\text { Jumlah siswa yang mengikuti } \\
\text { tes }\end{array}$ & 24 \\
\hline Jumlah siswa yang tuntas & 19 \\
\hline $\begin{array}{l}\text { Jumlah siswa yang tidak } \\
\text { tuntas }\end{array}$ & 5 \\
\hline Nilai tertinggi & 80 \\
\hline Nilai terendah & 50 \\
\hline Rata-rata nilai hasil belajar & 66,25 \\
\hline Persentase ketuntasan & $79 \%$
\end{tabular}

Dari tabel di atas dapat dilihat bahwa dari 24 siswa yang mengikuti evaluasi, terdapat 19 siswa yang tuntas dan 5 siswa tidak tuntas, sehingga ketuntasan belajar siswa pada siklus I ini mencapai $79 \%$ dengan nilai rata-rata 66,25.

\section{e. Refleksi}

Ketuntasan klasikal hanya mencapai 79\% sedangkan ketuntasan yang ditetapkan adalah 85\%. Hasil observasi juga menunjukkan hasil yang kurang memuaskan. Adapun tindakantindakan perbaikan yang akan ditempuh adalah:

1) Guru harus lebih memberikan kesempatan kepada siswa dalam mengemukakan pendapat atau jawaban tanpa harus terbebani apakah pendapat atau jawaban tersebut benar atau salah

2) Guru meminta tiap kelompok untuk mendiskusikan hasil berpasangan dengan temannya dan melatih siswa untuk dapat menyimpulkan sendiri materi yang telah di ajarkan.

3) Sebelum pembelajaran selesai guru meminta siswa untuk mencatat jawaban benar yang telah didiskusikan bersama.

4) Guru lebih mengatur alokasi waktu dalam setiap kegiatan selama pembelajaran berlangsung.

\section{Siklus II}

a. Perencanaan

Pada tahap perencanaan ini juga dilakukan persiapan-persiapan sebagai berikut.
1) Meyiapkan kembali perangkat pembelajaran yang meliputi penyusunan rencana pelaksanaan pembelajaran, kelompok yang memiliki kemampuan akademik heterogen dengan anggota 4 - 5 orang, pedoman observasi aktivitas guru, pedoman observasi aktivitas siswa, menyiapkan lebar kerja siswa (LKS) sebabagai bahan diskusi, dan membuat soal evaluasi siklus II lengkap dengan pedoman pensekorannya.

2) Memeriksa kembali prasarana yang diperlukan siswa dalam menyelesaikan LKS dan soal evaluasi. Prasarana yang dimaksud antara lain penggaris, kertas buram, pensil dan lain sebagainya.

\section{b. Pelaksanaan tindakan}

Guru melaksanakan pembelajaran sesuai dengan rencana pelaksanaan pembelajaran (RPP) yaitu dengan menjelaskan materi kemudian guru membagikan LKS kepada setiap siswa. Setelah itu guru mengorganisasikan siswa dalam kelompokkelompok yang terbentuk pada siklus I dan siswa belajar dengan langkah-langkah yang ada pada model pembelajaran Cooprative Integreted Reading and Composition (CIRC) berbasis Inquiry.

Selama diskusi berlangsung guru memantau kerja tiap-tiap kelompok dan membimbing siswa yang mengalami kesulitan. Setelah diskusi selesai guru bersama-sama siswa menyimpulkan materi yang telah didiskusikan dan memperbaiki hasil presentasi siswa yang belum sesuai dengan konsep matematika yang benar.

\section{c. Hasil observasi}

1. Aktivitas guru

Data yang diperoleh dari observasi aktivitas guru dapat dilihat pada tabel 6

TABEL 6

HASIL PERHITUNGAN AKTIVITAS GURU SIKLUS II

\begin{tabular}{ccc}
\hline Pertemuan & $\begin{array}{c}\text { Skor Aktivitas } \\
\text { Guru }\end{array}$ & Kategori \\
\hline 1 & 2,64 & Sangat Baik \\
\hline 2 & 2,79 & Sangat Baik \\
\hline
\end{tabular}


Guru melaksanakan kegiatan pembelajaran sesuai dengan Rencan Pelaksanaan Pembelajaran (RPP). Pengaturan waktu dilakukan dengan baik, melakukan pemantuan dan bimbingan secara merata pada tiap kelompok, menyampaikan kesimpulan materi dan memperbaiki hasil presentasi kelompok yang tidak sesuai dengan konsep yang benar.

\section{Aktivitas sisiwa}

Ringkasan hasil observasi siswa dapat dilihat pada tabel 7 berikut:

TABEL 7

RINGKASAN HASIL AKTIVITAS SISWA

SIKLUS II

\begin{tabular}{ccc}
\hline Pertemuan & $\begin{array}{c}\text { Skor aktivitas } \\
\text { siswa }\end{array}$ & Katagori \\
\hline 1 & 10,84 & Aktif \\
\hline 2 & 12,68 & aktif \\
\hline
\end{tabular}

Ada peningkatan skor rata-rata aktivitas siswa dari siklus I. Dari hasil observasi aktivitas siswa pada siklus II didapatkan bahwa siswa antusias dengan model pembelajaran yang diterapkan karena model pembelajaran ini melibatkan semua siswa. Siswa mempuyai tugas masing-masing dalam kelompoknya dan siswa merasa tertantang untuk mengeluarkan pendapatnya ketika berdiskusi.

\section{d. Hasil evaluasi}

Hasil evaluasi siswa selengkapnya dapat dilihat pada tabel 8

TABEL 8

RINGKASAN HASIL EVALUASI SIKLUS II

\begin{tabular}{lc}
\hline $\begin{array}{l}\text { Jumlah siswa yang } \\
\text { mengikuti tes }\end{array}$ & 21 \\
\hline Jumlah siswa yang tuntas & 19 \\
\hline $\begin{array}{l}\text { Jumlah siswa yang tidak } \\
\text { tuntas }\end{array}$ & 2 \\
\hline Nilai tertinggi & 90 \\
\hline Nilai terendah & 50 \\
\hline Rata-rata nilai & 75,2 \\
\hline Prosentase ketuntasan & $90 \%$ \\
\hline
\end{tabular}

Terlihat bahwa dari 22 siswa yang mengikuti evaluasi, terdapat 19 siswa yang tuntas dan 2 siswa tidak tuntas, sehingga ketuntasan belajar siswa pada siklus II ini mencapai $90 \%$ dengan nilai rata-rata 75,2. Mengenai hasil evaluasi pada siklus II dan analisis dari hasil evaluasi tabel diatas dapat dilihat pada lampiran.

\section{e. Refleksi}

Berdasarkan data yang diperoleh dari tes evaluasi dan observasi yang dilakukan, terjadi peningkatan dari siklus sebelumnya. Ketuntasan klasikal sudah memenuhi standar yang ditetapkan yaitu sebesar 90\%. Aktivitas siswa termasuk dalam kategori aktif dan guru sudah melaksanakan pembelajaran sesuai dengan rencana pelakasanaan pembelajaran yang disepakati.

Kegiatan pembelajaran dilaksanakan sesuai dengan langkah-langkah pembelajaran yang tertuang dalam Rencana Pelaksanaan Pembelajaran (RPP) yang telah disusun. Respon siswa setelah guru melakukan kegiatan awal cukup baik. Setelah diinformasikan akan diterapkannya model pembelajaran Cooprative Integreted Reading and Composition (CIRC) berbasis Inquiry, siswa sangat antusias dan lebih semangat dalam belajar karena mereka akan mendapatkan pengalaman baru tentang belajar secara kooperatif.

Kegiatan inti dimulai dengan menjelaskan materi secara singkat oleh guru dan memberikan kesempatan bertanya kepada siswa terhadap materi yang belum dipahami. Siswa mendengarkan semua penjelasan dari guru. Sebelum masuk ke dalam kelompok diskusi, guru membagikan LKS kapada masing-masing kelompok kemudian siswa diminta bekerja sama dengan teman kelompoknya selama waktu yang telah ditentukan. Setelah berdiskusi dengan teman kelompoknya yang terdiri dari 4-5 siswa tiap kelompok dan membahas hasil kerjanya yang dipimpin oleh ketua kelompok. Masing-masing wakil dari anggota kelompok secara bergiliran mengerjakan lembar kerja di papan tulis, siswa yang lain memperhatikan dan memberi tanggapan. Langkah akhir dari pembelajaran yang dilakukan adalah guru bersama-sama dengan siswa menyimpulkan materi yang didiskusikan.

Pada siklus II tahapan-tahapan yang akan dilaksanakan tidak jauh beda dari tahapan yang ada pada siklus I yaitu tahap perencanaan, pelaksanaan, observasi dan refleksi. Sebelum memulai proses 
kegiatan belajar mengajar guru telah membuat perencanaan yang meliputi Rencana Pelaksanaan Pembelajaran (RPP), lembar kerja siswa, soal evaluasi, kunci jawaban dan lembar observasi untuk siswa dan guru. Pada siklus II kegiatan pembelajaran dilaksanakan sesuai dengan langkah-langkah yang tertuang dalam Rencana Pelaksanaan Pembelajaran (RPP) yang di mulai dari pendahuluan dengan memberikan apersepsi, menyampaikan tujuan pembelajaran. Kegiatan inti dengan menyampaikan materi secara singkat oleh guru dan siswa belajar sesuai dengan langkah-langkah pada model pembelajaran kooperatif tipe Cooprative Integreted Reading and Composition (CIRC) berbasis Inquiry. Langkah akhir dari pembelajaran yang dilakukan adalah guru bersama-sama dengan siswa menyimpulkan materi yang didiskusikan, dan merefleksikannya.

Dalam tahap pelaksanaan proses belajar mengajar pada siklus II ini dilaksanakan untuk memperbaiki kekurangan-kekurangan atau kelemahan yang ada pada siklus I yaitu:

1. Cara mengajar guru masih terlalu cepat sehingga siswa kurang memahami materi yang disampaikan oleh guru. Hal ini ditindak lanjuti dengan guru harus memperbaiki cara menyampaikan materi sehingga siswa dapat mengerti terhadap materi yang disampaikan.

2. Sebagian siswa belum dapat memanfaatkan kesempatan dalam berdiskusi dengan pasangannya. Hal ini dapat ditindak lanjuti dengan pemberian motivasi oleh guru tentang pentingnya berdiskusi dengan temannya.

3. Sebagian siswa belum terbiasa bekerja kelompok, sehingga tugas kelompok dipercayakan pada anak yang paling pandai dalam kelompoknya, hanya agar tugas tersebut segera dapat diselesaikan tanpa mempertimbangkan setiap anggota kelompok yang belum memahami materi yang sedang dibahas. Hal ini ditindak lanjuti dengan cara guru mengingatkan kembali pada siswa tentang memanfaatkan kesempatan untuk berdiskusi dengan baik dan semua anggota harus lebih berperan aktif dalam diskusi kelompok berdasarkan hasil diskusi dengan temannya yang harus dikemukakan dalam diskusi kelompok.

4. Siswa masih kesulitan dalam menyimpulkan materi yang dibahas. Hal ini dapat ditindak lanjuti dengan membimbing siswa dalam menyimpulkan materi yang sudah dibahas.
Beradasrkan analisis data pada siklus I menunjukkan bahwa aktivitas siswa tergolong aktif dengan rata-rata skor aktivitas siswa sebesar 10,84. Aktivitas guru dengan rata-rata skor 2,64 dengan kategori baik. Rata-rata nilai hasil belajar siswa adalah 66,25 dengan ketuntasan klsikal mencapai 79\%. Pencapaian tersebut belum memenuhi standar ketuntasan minimal yang ditetapkan yaitu sebesar $85 \%$.

Pada siklus II, terdapat peningkatan aktivitas siswa yaitu pada siklus I rata-rata skor aktivitas siswa adalah 10,84 dengan kategori aktif, pada siklus II terjadi peningkatan menjadi 12,68 dengan kategori aktif. Aktivitas guru termasuk dalam kategori sangat baik dengan skor rata-rata 2,79. Nilai rata-rata hasil belajar siswa meningkat dari sebelumnya yaitu 66,25 Ketuntasan klasikal mencapai 79\% meningkat dari ketuntasan klasikal pada siklus I yang hanya mencapai 88\%. Dengan demikian pada siklus II ini menunjukkan bahwa hasil belajarnya sudah mencapai ketuntasan klasikal.

Hal ini menggambarkan bahwa siswa telah terbiasa dengan model pembelajaran kooperatif tipe Cooprative Integreted Reading and Composition (CIRC) berbasis Inquiry. Siswa sudah bisa memahami penjelasan materi dari guru. Siswa lebih terampil dalam menyelesaikan LKS secara individu dan kelompok. Sebagian besar siswa juga telah berperan aktif dalam kelompoknya, dapat bertukar informasi dengan anggota yang lain, dapat membantu anggota lain yang kesulitan dalam memahami materi. Siswa juga telah dapat bekerjasama dan melaksanakan evaluasi dengan baik.

\section{SIMPULAN DAN SARAN}

\section{Simpulan}

Penerapan model pembelajaran tipe Cooprative Integreted Reading and Composition (CIRC) berbasis Inquiry dapat meningkatkan aktivitas belajar siswa dilihat dari skor aktivitas siswa pada siklusi I adalah 10,84 dengan kategori aktif meningkat menjadi 12,68 pada siklus II dengan kategori aktif. Dan dapat meningkatkan hasil belajar siswa kelas IX_6 SMP Negeri 1 Pujut yang dilihat dari rata-rata hasil belajar siswa siklus I yaitu 66,25 , rata-rata nilai evaluasi hasil belajar siswa siklus II sebesar 75,8 serta persentase ketuntasan klasikal pada siklus I yaitu $79 \%$, dan meningkat pada siklus II sebesar $88 \%$. 


\section{Saran-saran}

Model pembelajaran kooperatif tipe Cooprative Integreted Reading and Composition (CIRC) berbasis Inquiry menjadi salah satu alternatif metode bagi guru dalam pembelajaran matematika sehingga pembelajaran menjadi lebih aktif, kreatif, efektif, inovatif dan menyenangkan.

\section{UCAPAN TERIMA KASIH}

Dengan penuh rasa hormat, saya ucapkan teimakasih kepada:

1. Kepala Dinas Pendidikan Kabupaten Lombok Tengah yang telah memfasilitasi, mengizinkan penulis untk mengadakan penelitian hingga dapat terlaksana dengan baik.

2. Bapak Kepala sekolah yang selalu memberi dukungan sejak awal hingga terlaksananya penelitian ini dengan baik.

3. Rekan-rekan guru yang telah memberi dukungan baik secara moral maupun tindakan langsung dalam pelaksanaan penelitian ini.

\section{REFERENSI}

[1]. Arifin, Z. (2009). Evaluasi Pembelajaran PrinsipTeknik-Prosedur. Bandung: PT REMAJA ROSDAKARYA.

[2]. Corebima., Al-idrus A. (2009). Penelitian Tindakan Kelas (Modul Diklat Sertifikasi Guru). Mataram: UNIVERSITAS MATARAM.

[3]. Djamarah, Syaiful Bahri. (2002). Psikologi Belajar. Banjarmasin: PT RINEKA CIPTA.

[4]. Hamalik, U. (2001). Proses Belajar Mengajar. Bandung : PT Bumi aksara.

[5]. Hanafiah, Nanang, dkk. (2009). Konsep Strategi Pembelajaran. Bandung: PT Refika Aditama.

[6]. Lie, Anita. (2010). Cooperative Learning. Jakarta: PT Gramedia.

[7]. Mahfiroh. (2009). Strategi Pembelajaran Efektif. Semarang: PT Sindur Pres

[8]. Sudjana, N. (1989). Penilaian Hasil Proses Belajar Mengajar. Bandung: Sinar Baru Algensindo.

[9]. Sudjana, Nana. (1987). Dasar-Dasar Proses Belajar Mengajar. Bandung: Sinar Baru Algensindo.

[10]. Suprijono, Agus. (2009). Cooperative Learning (Teori dan Aplikasi Paikem). Surabaya: Pustaka Pelajar.

[11]. Trianto. (2007). Model-model Pembelajaran Inovatif Berorientasi Konstruktivistik (Konsep, Landasan Teoritis - Praktis dan Implementasinya. Surabaya: PRESTASI PUSTAKA. 